\title{
Implementing “Job Enrichment” with using Ergonomic Checkpoints in an 'Appreciative Way' at a Manufacturing Company in an Industrially Developing Country and its Meta-reflection
}

\section{Farahnaz Dastranj ${ }^{1}$ and Faramarz Helali ${ }^{2 *}$}

${ }^{1}$ Department of Occupational Health, International Campus of Shahid Sadoughi University of Medical Sciences (IC-SSUMS), Yazd, Iran

${ }^{2}$ Department of Business Administration, Technology and Social Sciences, Lulea University of Technology, 971-87 Lulea, Sweden

\begin{abstract}
The aim of this study was to create ergonomics and human factors awareness and wakefulness in a Pharmaceutical Manufacturing Company with emphasis on understanding the importance of improving safety, health, and work condition. The study sought to develop and implement one kind of "Job enrichment" with the purpose of improving employees' competence and also to motivate participation at the workplaces in an 'appreciative way'. The survey approach was used. Data was collected from 60 selected individuals from different organizational levels using the participatory ergonomics process that entailed the use of an actionchecklist and ergonomic checkpoints, as well as the review of organizational documents. Eighty seven percent of these study participants were male while the remaining $13 \%$ were female. The participants had an average age of 38 years with the standard deviation of 9.74 . They had 11.81 years of service in average with the standard deviation of 9.76 . In the data collection procedure, technical sessions, based on action learning, which lasted for $30,25 \mathrm{~h}$, or 1657 man h, was also held for the participants. In the data collection, the participants were made to study the action-checklist before and after completing the ergonomic checkpoints. This resulted in a 0.3 percent improvement in the technical capabilities of the participants and improved their social skills and their interest in participation in the company during this study. Based on the analysis of participants' feedbacks on the implementation of different work evaluation approaches and their reflection from learning, key findings were made through intentional learning, based on a systemic pre-intervention ergonomics work process on how the participants could be empowered in technical and social skills.
\end{abstract}

Keywords: Ergonomic checkpoints; Job enrichment; Participatory ergonomics process; Appreciative inquiry and way; Industrially developing countries

\section{Introduction}

Necessity for applying action-checklists and various checkpoints in industrially developing countries

Various action checklists have been developed for different purposes, usually as tools for prioritizing action plans in ergonomic design or redesign, comparative studies and training [1,2]. There are also other types of ergonomic checkpoints listed by Kogi [2], applied through serial participatory steps, that have been used in training programs to improve workplace conditions in small-scale workplaces in Industrially Developing Countries (IDCs) in Asia. Described these checkpoints as generally a compilation of practical improvement options in a broad range of technical areas, such as materials handling, workstation design, physical environment and work organization. Usually, "action checklists" comprising the tiles of the checkpoints are used together. A clear focus is placed on readily applicable low-cost options. Three common features of these various checkpoints appear to be important. 'First, the checkpoints represent typical good practices in multiple areas. Second, each how-to section of these checkpoints presents simple improvements reflecting basic ergonomic principles. Third, the illustrated checkpoints accompanied by corresponding checklists are used as group work tools in short-term training courses' [2]. Ergonomic Checkpoints have been developed with the objective of offering practical, low-cost situations to ergonomic problems, particularly for small and medium-sized enterprises 'A participatory approach is also the most effective and sustainable way to promote and practice ergonomics in developing countries' [2-5]. However, organizations ability to access ergonomics knowledge is usually very difficult, especially in IDCs [6]. For this reason, the building of ergonomics awareness and furthermore, the awakened need of change is certainly the first phase of an intentional learning for the proposed model for ergonomics intervention programme technique process [6] or the application of ergonomics to work system [7]. As found by Helali [6], there is the need to pay attention when presenting and applying different ergonomics intervention techniques with three different 'process phases' (i.e., Routine task/Pre-intervention, Modified task/ Process intervention, and new task/Post-intervention) in industrial firms in IDCs, such as Iran.

\section{The use ergonomic checkpoints in iran}

The concept of ergonomics is broad, system-oriented and interaction-related $[6,8]$ with a focus on understanding $[6,9]$. Action learning is also 'a continuous process of learning and reflection with an intention of getting things done. Through action learning individuals learn with and from each other by working on real problems and reflecting on their own experiences [10]. The action learning approach is adapted to support participants' involvement by doing or to show how ergonomics 'know-how' (i.e., learning by doing) can be introduced

*Corresponding author: Faramarz Helali, Department of Business Administration, Technology and Social Sciences, Lulea University of Technology, SE-971 87, Lulea, Sweden, Tel: +46738070567; Fax: +46920491030; E-mail: Faramarz.Faramarz@ltu.se

Received May 28, 2016; Accepted July 18, 2016; Published July 25, 2016

Citation: Dastranj F, Helali F (2016) Implementing "Job Enrichment" with using Ergonomic Checkpoints in an 'Appreciative Way' at a Manufacturing Company in an Industrially Developing Country and its Meta-reflection. J Ergonomics 6: 172. doi:10.4172/2165-7556.1000172

Copyright: (c) 2016 Dastranj F, et al. This is an open-access article distributed under the terms of the Creative Commons Attribution License, which permits unrestricted use, distribution, and reproduction in any medium, provided the original author and source are credited. 
by management into organizations $[6,11,12]$. For this reason, [13] has emphasized the use of the combined methods. This is because, very often, two or more of the classic technique methods are used together in carrying out a Macroergonomic analysis, intervention, and or evaluation [14]. In a study by Helali [15] in which the Ergonomic Checkpoint was used to support a participatory ergonomic intervention, based on an action learning in an IDC, it was observed that the use of the participatory ergonomics process at the organizational level could bring a positive cultural change in the workplace $[16,17]$. Based on this finding [15], made the following postulations relative to the collective use of the ILO ergonomics checkpoints book; your/our limitation is not people or managers and top managers at work or the big cultural issue of teamwork. Your/our limitation for the promotion of ergonomics may be that your/our knowledge and experiences within the IDCs are not yet sufficient. These postulations brings to the fore the participatory ergonomics issues concerning the ability to train people (as a facilitator role) in organizations in IDCs, and how reflective learning and action $[6,11]$ can be used to guide the effective application of the ILO ergonomics checkpoints book as well as the different ergonomics intervention techniques in an IDC like Iran. The purpose of this study therefore, was to create ergonomics and human factors awareness and wakefulness in a Pharmaceutical Manufacturing Company with emphasis on understanding the importance of improving safety, health, and work condition. In other words, the study sought to introduce "Job enrichment" in the company's work environment that could enhance employees' competences, and motivate employees' participation in an 'appreciative way' through the development and implementation of techniques for systemic ergonomics intervention work. This study was therefore underlined by the following question: "How can pre-ergonomics intervention work, using participatory ergonomics approach, be introduced in the Pharmaceutical and Hygienic Manufacturing Company, in order to ensure the successful "job enrichment" of the employees' work environment towards appreciative participation and enhanced competences.

\section{Importance of 'Macroergonomics Attitude' and Necessity of Employees' Involvement}

Helali [6] has observed that it is insufficient for firms rely on only training; awareness creation; ergonomics; and interventions when addressing safety, health, and ergonomics issues. For this reason, he noted that both practical learning and reflection learning should be provided at all levels of the organization. Such provision could lead to the emergence of better organizational interactions, underlined by macroergonomics attitude in firms, when implementing systemic ergonomics intervention at the workplace [12]. According to Hendrick and Kleiner Brian [14], macroergonomics is top-down (i.e., strategic approach to analysis), bottom-up (i.e., participatory ergonomics), and middle-out (i.e., focus on processes). Central to Macroergonomics is the expectation that analysis and design of work system will be participatory in nature $[18,19]$. The use of participatory ergonomics interventions methods in the workplace by firms in both Industrialized Countries (ICs) and Industrial Developing Countries (IDCs) have found increasing applications [6,20-25]. For this reason, participatory ergonomics can be regarded as a philosophy, an approach or strategy, a program, or a set of techniques and tools [24]. Wilson and Haines define participatory ergonomics as the involvement of people in planning and controlling a significant amount of their own work activities, with sufficient knowledge and power to influence both process and outcomes to achieve desirable goals $[24,26]$. Thus, participatory ergonomics is complex and diverse. This means that there is a range of models and ways of carrying out participatory ergonomics, and a multiplicity of tools and methods employed within participatory ergonomics initiatives [24]. Participatory ergonomics is therefore viewed as offering a common set of advantages [24,27]. For this reason, as noted by Haines and Wilson [28], several varying methods have been developed for use in participatory ergonomics initiatives. Since participatory ergonomics require employee involvement [29], has argued that using different employees' involvement techniques often provide different effects, and by implication underestimating the techniques potential. As such, the employees' involvement process entails the use of the entire capacity of workers, designed to encourage employees' commitment to organizational success [29] points out that 'it is not a true unitary scientific concept, but rather a useful catchall term for a variety of approach, all of which employee participation ( $\mathrm{p}: 3)^{\prime}$.

In this study, therefore, the involvement of employees (workers, supervisors, and managers) was used as an approach in a collaborative process towards encouraging them to use their whole capacity and commitment in their works while improving their learning potentials and increasing organizational knowledge. For this reason, participatory ergonomics approach is viewed as an involvement of employees (at the different organizational levels) with the purpose of getting their contributions to the design and analysis of ergonomics-related issues $[15,24,30,31]$. Thus, 'involvement in an ergonomic development and implementation process can lead to faster and more thorough learning of a new system or procedure that, in turn can result in reduced training costs and improved job performance' [30]. The long-term implication of using participatory ergonomics is that individuals will be able to exert some control over their environment. According to Noro and Kleiner [31] this would lead to feedback, self-determination, and selfregulation, helping the end-user to improve their work environment and working conditions.

\section{Methods}

\section{Material and procedure}

In this study, the Farsi version of the Ergonomic Checkpoints (ILO, 2015, Edition Free) which provides practical and easy-to-implement solutions for improving safety, health and working conditions was used to guide the data collection tool in an appreciative way $[32,33]$. This Farsi version was a direct translation of the original Ergonomic Checkpoints [16] developed for application in both industrial developed and industrial developing countries. It is comprised of a checklist, checkpoints on 9 different topics, as well as important principles concerning safety, health and ergonomics. The nine topical elements are as follows: materials storage and handling (17 checkpoints), hand tools (14 checkpoints), productive machine safety (19 checkpoints), improving workstation design (13 checkpoints), lighting (9 checkpoints), premises (12 checkpoints), control of hazardous substances and agents ( 10 checkpoints), welfare facilities (11 checkpoints), and work organization (27 checkpoints).

The study participants, who constituted a wok group, included managers, heads, supervisors, HSE personnel and workers. In all sixty (60) participants were selected out of the company's population of two hundred and seventy (270) employees. The sampling methods used in the particpants' selection included the complete count method for the HSE personnel and the simple sampling method for the workers. The demographics of the particpants is shown in Table 1.

According to Table 1, the average age of participants in four groups of managers, supervisors, HSE unit personnel and operational staff was 
Citation: Dastranj F, Helali F (2016) Implementing “Job Enrichment” with using Ergonomic Checkpoints in an 'Appreciative Way' at a Manufacturing Company in an Industrially Developing Country and its Meta-reflection. J Ergonomics 6: 172. doi:10.4172/2165-7556.1000172

Page 3 of 14

\begin{tabular}{|c|c|c|c|c|c|}
\hline Variable & & $\begin{array}{c}\text { Middle } \\
\text { School and diploma (Number \%) }\end{array}$ & $\begin{array}{c}\text { Diploma } \\
\text { (Number \%) }\end{array}$ & $\begin{array}{c}\text { MA } \\
\text { Degree (Number \%) }\end{array}$ & $\begin{array}{l}\text { PhD Degree } \\
\text { (Number \%) }\end{array}$ \\
\hline \multirow{4}{*}{ Education level } & Managers & $1(\% 16 / 6)$ & - & $2(\% 33 / 3)$ & $3(\% 50)$ \\
\hline & Supervisors & $7(\% 63 / 6)$ & - & $4(\% 36 / 3)$ & - \\
\hline & HSE unit personnel & $2(\% 66 / 6)$ & - & - & $1(\% 33 / 3)$ \\
\hline & Operational staff & $32(\% 78)$ & $4(\% 9 / 75)$ & $5(\% 12 / 19)$ & - \\
\hline \multirow{5}{*}{ Sex } & & \multicolumn{2}{|l|}{ Men (Number \%) } & \multicolumn{2}{|c|}{ Women (Number \%) } \\
\hline & Management & \multicolumn{2}{|l|}{$5(\% 83 / 3)$} & \multicolumn{2}{|c|}{$1(\% 16 / 6)$} \\
\hline & Supervisors & \multicolumn{2}{|l|}{$10(\% 90 / 9)$} & \multicolumn{2}{|c|}{$1(\% 9 / 09)$} \\
\hline & HSE unit personnel & \multicolumn{2}{|l|}{$2(\% 66 / 6)$} & \multicolumn{2}{|c|}{$1(\% 33 / 3)$} \\
\hline & Operational staff & \multicolumn{2}{|l|}{$36(\% 87 / 8)$} & \multicolumn{2}{|c|}{$5(\% 12 / 19)$} \\
\hline \multirow{5}{*}{$\begin{array}{c}\text { Age } \\
\text { (years) }\end{array}$} & & \multicolumn{2}{|l|}{ Average } & \multicolumn{2}{|c|}{ Standard deviation } \\
\hline & Managers & \multicolumn{2}{|l|}{$50 / 16$} & \multicolumn{2}{|c|}{$9 / 28$} \\
\hline & Supervisors & \multicolumn{2}{|l|}{$41 / 72$} & \multicolumn{2}{|l|}{$8 / 36$} \\
\hline & HSE unit personnel & \multicolumn{2}{|l|}{47} & \multicolumn{2}{|c|}{$10 / 58$} \\
\hline & Operational staff & \multicolumn{2}{|l|}{$34 / 56$} & \multicolumn{2}{|c|}{$8 / 02$} \\
\hline \multirow{5}{*}{ Work experience (years) } & & \multicolumn{2}{|l|}{ Average } & \multicolumn{2}{|c|}{ Standard deviation } \\
\hline & Managers & \multicolumn{2}{|l|}{$18 / 66$} & \multicolumn{2}{|l|}{$12 / 16$} \\
\hline & Supervisors & \multicolumn{2}{|l|}{$16 / 81$} & \multicolumn{2}{|l|}{10} \\
\hline & HSE unit personnel & \multicolumn{2}{|l|}{$18 / 33$} & \multicolumn{2}{|c|}{$12 / 58$} \\
\hline & Operational staff & \multicolumn{2}{|l|}{$8 / 60$} & \multicolumn{2}{|c|}{$7 / 98$} \\
\hline
\end{tabular}

Table 1: Data related to distribution of respondents based on personal Information of participants in a two-stage investigation of checklist and questionnaire with a common code for each participant.

$50 / 16,41 / 72,47,34 / 56$ years; average of the experience of respondents in each group was $18 / 66,16 / 81,18 / 33,8 / 60$ years, respectively.

Based on Table 1, most of the participants in the group of managers have a postgraduate or $\mathrm{PhD}$ degree while HSE unit personnel have a diploma or PhD degree. In the operational staff group, most staffs have a diploma or MA degree. All subjects in the managers' group sample included $\% 83 / 3$ men and $\% 16 / 6$ women. In the supervisors group, all subjects included \%90/9 men and \%9/09 women. In HSE unit personnel, all subjects included $\% 66 / 6$ men and $\% 33 / 3$ women. Sample of operational staff also included $\% 87 / 8$ men and \%12/19 women.

Table 2 shows the distribution of participants who respondents according based on business unit in separated organizational posts. In the managers' group, largest group of respondents was related to business unit. In the supervisors group, most responses were related to the production unit of non-antibiotics while in the employee group, most respondents were in the official and packaging production units.

It should be explained that HSE unit was working in the form of a single unit (rather than separate units) in the related company. Therefore, there was no need to unit separation.

As observed in Table 3, the technical sessions held for the participants lasted for 30, $25 \mathrm{~h}$, or $1657 \mathrm{man}$ h, totally.

In the procedure for data collection, the ELMIRI ergonomics index [34] was used as a guide for the selection of problematic working areas. The checklist was firstly used, followed by the application of the "Ergonomic Checkpoints" [16], after which the checklist was applied again. A simple questionnaire was then used in two stages to collect feedback about the checklists. A review of organizational documents and minutes of the HSE Division for the previous three (3) years prior to this study was then conducted. Project evaluation exercises was carried out variously, as outlined in the sections below, by organizing evaluation workshop, interviewing participants for feedbacks, and holding technical appraisal meetings with the senior managers during a one-year period leading to 2012 .
Applying an ergonomics index to propose "what is the ergonomics conditions before the starting of the study?" by an expert of department of HSE: ELMIRI ergonomic index [34] was introduced by a Finnish institute to evaluate ergonomics checkpoints. A health expert with the company employed the index to determine the ergonomic condition at the beginning of a study titled "where are we ergonomically?" using ILO's checklist of the ergonomic checkpoints (2010) (Table 4).

Applying the checklist before introducing the ergonomic checkpoints book

The first set technical sessions: To avoid disrupting daily work in the company, the people under study: were divided into small groups so as to be provided with better training and learning. This method was applied to different levels of the company in the form of technical sessions for the first time.

In the first round of the meetings, the attendees were provided with explanations on how to fill out the checklist of the ergonomic checkpoints as well as explanations on the research's procedure. Also, the checklist taken from ILO's "Ergonomic Checkpoints" (2010) was provided to the attendees as mentioned below: At the first meeting, the attendees were divided into four groups: Group one (including people engaged in production activities plus people engaged in service and transportation activities), group two (including people engaged in production activities plus people working in the warehouses), group three (including people engaged in production activities plus people from the technical and engineering department as well as people from the security department) and group four (including people from the administrative department plus people working in the laboratory). Also, the participants were advised on how to fill out the checklist of the ergonomic checkpoints in a better manner. Each meeting held for each group of people lasted for one hour. Also, the managers were separately provided with explanations on how to fill out the checklist, and sample checklist were completed for them.

Applying a simplequestionnaire for the first time: A questionnaire was designed to achieve a better understanding of the feedback from 
Citation: Dastranj F, Helali F (2016) Implementing “Job Enrichment” with using Ergonomic Checkpoints in an 'Appreciative Way' at a Manufacturing Company in an Industrially Developing Country and its Meta-reflection. J Ergonomics 6: 172. doi:10.4172/2165-7556.1000172

Page 4 of 14

\begin{tabular}{|c|c|c|c|c|c|c|c|c|c|c|c|}
\hline \multirow{2}{*}{ Variable } & & \multirow{2}{*}{$\begin{array}{l}\text { Official } \\
\text { N (\%) }\end{array}$} & \multirow{2}{*}{$\begin{array}{l}\text { Sentry } \\
\mathrm{N}(\%)\end{array}$} & \multirow{2}{*}{$\begin{array}{c}\text { Technical } \\
\text { Engineering } \\
\mathbf{N}(\%)\end{array}$} & \multirow{2}{*}{$\begin{array}{l}\text { Store } \\
\mathbf{N}(\%)\end{array}$} & \multirow{2}{*}{$\begin{array}{l}\text { Laboratory and } \\
\text { Research } \\
\text { N (\%) }\end{array}$} & \multicolumn{5}{|c|}{$\begin{array}{l}\text { Production } \\
\quad \mathrm{N}(\%)\end{array}$} \\
\hline & & & & & & & Packing & $\begin{array}{c}\text { Production of } \\
\text { antibiotics }\end{array}$ & $\begin{array}{c}\text { Production of } \\
\text { non-antibiotics }\end{array}$ & Sterile & Syrup mg \\
\hline \multirow{4}{*}{$\begin{array}{c}\text { Business } \\
\text { Unit }\end{array}$} & Managers & $3(50 \%)$ & - & $1(\% 16 / 6)$ & $1(\% 16 / 6)$ & - & $1(\% 16 / 6)$ & - & - & - & - \\
\hline & $\begin{array}{l}\text { Super } \\
\text { visors }\end{array}$ & - & $1(\% 9 / 09)$ & $1(\% 9 / 09)$ & $1(\% 9 / 09)$ & - & $2(\% 18 / 18)$ & $3(\% 27 / 27)$ & $1(\% 9 / 09)$ & $1(\% 9 / 09)$ & $1(\% 9 / 09)$ \\
\hline & HSE unit & $3(\% 100)$ & - & - & - & - & - & - & - & - & - \\
\hline & $\begin{array}{c}\text { Operational } \\
\text { staff }\end{array}$ & $10(\% 24 / 39)$ & $3(\% 7 / 31)$ & $3(\% 7 / 31)$ & $4(\% 9 / 75)$ & $2(\% 4 / 87)$ & $\begin{array}{c}10 \\
(\% 24 / 39)\end{array}$ & $3(\% 7 / 31)$ & $3(\% 7 / 31)$ & $2(\% 4 / 87)$ & $1(\% 2 / 43)$ \\
\hline
\end{tabular}

Table 2: Distribution of respondents based on business unit in separated organizational posts.

\begin{tabular}{|c|c|c|c|c|c|c|c|}
\hline \multirow[b]{2}{*}{ Session } & \multirow[b]{2}{*}{ Topic } & \multicolumn{4}{|c|}{ Number of participants } & \multirow{2}{*}{$\begin{array}{l}\text { Total technical } \\
\text { session duration } \\
\text { (hour) }\end{array}$} & \multirow{2}{*}{$\begin{array}{c}\text { Total technical session duration } \\
\text { in terms of man hour ( } 60 \\
\text { participants) }\end{array}$} \\
\hline & & Group one & $\begin{array}{c}\text { Group } \\
\text { two }\end{array}$ & $\begin{array}{l}\text { Group } \\
\text { three }\end{array}$ & $\begin{array}{l}\text { Group } \\
\text { four }\end{array}$ & & \\
\hline Session one & $\begin{array}{l}\text { Familiarity with the research project and } \\
\text { how to improve safety, health and working } \\
\text { conditions }\end{array}$ & 20 & 20 & 20 & - & 4.5 & 270 \\
\hline Session two & Familiarity with how to fill out ILO's checklists & 18 & 18 & 18 & 6 & 3.5 & 210 \\
\hline Session three & Material storage and handling standards & 18 & 18 & 18 & - & 4.5 & 243 \\
\hline Session four & Productive machine safety standards & 18 & 18 & 18 & - & 4.5 & 243 \\
\hline Session five & Hand tools standards & 30 & - & - & - & 1.5 & 45 \\
\hline Session six & $\begin{array}{l}\text { Improving workstation design and lighting } \\
\text { standards }\end{array}$ & 24 & 18 & 18 & - & 4.5 & 243 \\
\hline Session seven & Work organization standards & 24 & 18 & 18 & - & 4.5 & 243 \\
\hline Session eight & $\begin{array}{l}\text { Familiarity with how to fill out ILO's checklists } \\
\text { in the second stage }\end{array}$ & \multicolumn{4}{|c|}{60} & 0.25 (15 minutes) & 15 \\
\hline Session nine & Evaluation workshop & \multicolumn{4}{|c|}{58} & 2.5 & 142.5 \\
\hline Total & - & \multicolumn{4}{|c|}{-} & 30.25 & 1657 \\
\hline
\end{tabular}

Table 3: Technical sessions and their duration in terms of hour and man hour.

Action Category Levels*1 2345

Ergonomics Index 81-100 61-80 41-60 21-40 0-20

*Action categories:

1) Working conditions are acceptable (Very good ergonomics condition=1). Also, attention should be focused on priorities.

2) Working conditions are acceptable (Good ergonomics condition=2) and corrected measures may be needed. Attention should be focused on priorities.

3) Further investigation and intervention is needed by Intervention team (Average ergonomics condition=3). Corrective measures are required. Attention should be focused on priorities.

4) Further investigation and intervention are needed by group work (Poor ergonomics condition=4). Corrective measures are required soon. Attention should be focused on priorities.

5) Further investigation and intervention are needed by group work (Very poor ergonomics condition). They must take corrective action. Corrective measures are required soon.

Table 4: Guide for the selection of problematic working areas checklist.

the checklist usage. The questionnaire included open-ended and closeended questions on six topics including "research", "technical session", "checklist", "learning", "teamwork", and "research continuation". The close-ended questions provided options such as "to a very high extent", "to a high extent", "to a medium extent", "to a low extent", and "to a very low extent" based on the Likert scale. Each option was assigned a score ranging from zero to 4 .

Applying the checklist after introducing the ergonomic checkpoints book: The second set technical sessions: ILO's "Ergonomic Checkpoints" (edition 2010) was translated and typed. Each checkpoint provided by this book was consisted of two parts: one page contained various headings such as "relevant topic", "why", "how", "Some more hints" and "let's remember", and the second page contained pictures related to the topic. The checklist of the checkpoints was handed to the participants before the technical sessions start.
First, the checklist was distributed among the participants before the sessions by referring to their workplace so as to help them get prepared for the sessions. They were asked to read the checklist and share possible ambiguities with the HSE department, where the first author (as an internal facilitator) was stationed, before the sessions start in a bid to help them understand the checklist better and take part in the sessions with better preparations. The participants were divided into three main groups based on previous consultations with the managers of the production unit. The first technical session was titled "materials storage and handling standards". Each participant presented his checklist and raised ambiguities associated with it during the meeting. In general, the related issues were discussed by the attendees. The second session dealt with hand tools standards, namely the second topic on the "Ergonomic Checkpoints", which covered 14 topics. The checkpoints were discussed by the technical personnel and all the supervisors because of the importance attached to them. Each person presented his own checklist, and the technical personnel expressed their viewpoints for each topic thanks to their expertise.

The next technical session concerned the third topic on the "Ergonomic Checkpoints", dubbed "machine safety", which covered 19 topics. Some of the attendees showed creativity and innovation when making presentations and presented their checkpoints in a narrative way.

The session on improving workstation design and lighting was attended by the managers of the company. There were plans to invite to the meeting all the personnel and supervisors who had presented their checkpoints successfully in the previous sessions. A number of checkpoints related to improving workstation design and lighting that covered more important and relevant topics were selected to be presented during the meeting given the shortage of time. All the related checkpoints had been handed to all the personnel two days before the meeting so that they could have enough time to study them. 
The seventh session, attended by the managers, dealt with work organization, namely another topic covered by the "Ergonomic Checkpoints". Some 15 important points related to this topic were provided to the personnel to be presented during the meeting. The attendees experienced stress on the day of the meeting due to the complexity of managerial issues, which many of them personnel believed, had nothing to do with them. They complained that the materials could not be presented through the use of figures since they were different from the previous ones and difficult to memorize. All the three groups attended similar sessions covering the same topics during this period.

Besides, the first author of this article was beside the groups serving as the internal facilitator before and after the sessions. All the three groups were provided with tips on how to recomplete the primary checklist of the checkpoints in a final session so as to enable them to fill out the checklist accurately and submit them to the safety \& health department. Each participant was assigned an identification code with regard to completing the checklist and questionnaires in two stages.

Applying the simple questionnaire for the second times: Few additional open-ended questions were added to the original questionnaire, which was completed by the participants.

Review of organizational documents and minutes of HSE division during the last three years: Information about health-related cases concerning musculoskeletal disorders and diseases was collected from the health and safety department, and the rate of the incidents was examined. Also, data related to training courses and monthly meetings of the health and safety committee held over a three-year period were collected and examined.

\section{Project's evaluation}

Evaluating workshop: A workshop titled "what we learnt and where we are" was organized by the external facilitator (the second author) to evaluate the research project. The workshop, attended by 58 participants out of the total 60 participants, was held at the restaurant of the company after the working hours and lasted for $2.5 \mathrm{~h}$. This 2.5 hour period was added to the working hours of the personnel, who were also provided with transport services.

First, the attendees were asked to share their viewpoints and explain what they had learned from each other during the research project. The viewpoints of the participants were written down on a paper posted on the wall. Then, a model of the participatory ergonomics [28] was presented to the participants and they were told to which deliberate learning processes they had been exposed during the study. Then, six working groups were formed on a random basis to examine issues such as involvement aimed at participation and cooperation, trust, motivation, and qualification (technical and social skills) as well as the whole process for 20 minutes. Following that, each working group presented their results written down on papers posted on the wall for 5 minutes. The participants raised their questions after each group finished with presenting its results. The groups were also applauded by their colleagues. Meanwhile, the second author (the external facilitator), elaborated on the concept of the participatory ergonomics and differences between Macro and Micro ergonomics concepts, involvement aimed at participation and cooperation, the need for practical learning and its difference with theoretical training courses, the importance of research with the personnel and the company in the appreciative way, the role of facilitators, and the difference between technical sessions and training courses held in companies. The second author also explained what the above mentioned topics meant in a simple language. All the technical sessions and the evaluation workshop were taped and documented. A three-minute documentary clip about the whole process was produced after the workshop.

Interviews: One supervisor and a worker who was not primarily interested to take part in the technical sessions and also one of company's HSE experts were interviewed. These participants were asked to offer their viewpoints on the whole research project and the negative and positive outcomes of this type of research. The viewpoints were interpreted as a meta-reflection on the technical feedback based on the learning of reflection method.

The technical top managers session: At the end of the research project, the internal and external facilitators (the first and second authors of this article) held a two-hour technical meeting with 15 top managers of the company. During the meeting, a PowerPoint report on the research project was presented and the project's results were discussed by the attendees. Also, the external facilitator (the second author) explained issues such as what could be materialized with the support of the midlevel and senior managers, why the need for support is of great importance, which model of ergonomic intervention program technique process [6] had been exercised as a pre-intervention work process there, and how the participants attending the evaluation workshop evaluated their own performance. Questions raised by the managers were also answered during the meeting.

\section{Results and Inferences}

\section{Result of application of the ergonomics in}

Based on the evaluation of the ELMIRI index [34] shown in Table 4, the results of the ergonomic checkpoints filled out by the occupational health expert at different departments of the company showed that the total score given to the ergonomic condition in the company stood at 41 . It means that the ergonomic condition in the company fitted into level three and in need of further investigation and intervention by the facilitator intervention team. It also means that corrective measures should be adopted and that the attention should be focused on priorities.

\section{A Comparison of results of applying the checklist before and after introducing the ergonomic checkpoints book}

The results of this comparison are shown in Figures 1 and 2, as well as in Table 5. Figure 1 illustrates the results related to applying ILO's checklist before and after holding the technical sessions. It shows the effects of the technical sessions on safety, health and working conditions in terms of percentage.

The average, standard deviation, minimum and maximum of the scores given to safety, health and working conditions before applying the ergonomic checkpoints show that the minimum scores were low and that the lowest score belonged to work organization, followed by control of hazardous substances and agents, productive machine safety and lighting. These scores increased following the application of the checklist. The paired t-test also verifies that a significant difference has been observed in all the branches with the highest effect observed in control of hazardous substances and agents and the lowest effect observed in materials storage and handling.

A correlation test applied after employing the "Ergonomic Checkpoints" showed that all the scores had increased after applying the book [16]. It means that each topic of the book discussed during the technical sessions has had a positive effect on the previous and 
Citation: Dastranj F, Helali F (2016) Implementing “Job Enrichment” with using Ergonomic Checkpoints in an 'Appreciative Way' at a Manufacturing Company in an Industrially Developing Country and its Meta-reflection. J Ergonomics 6: 172. doi:10.4172/2165-7556.1000172

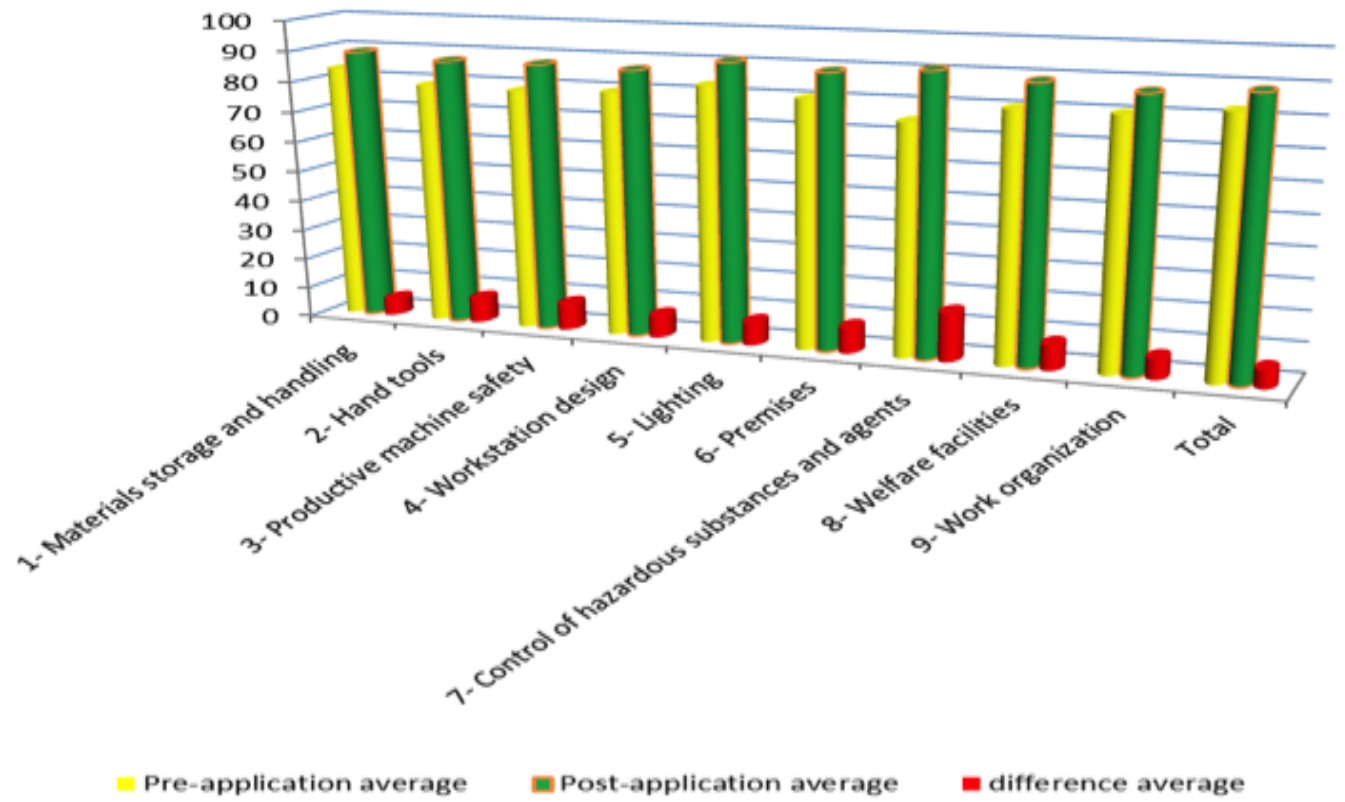

Figure 1: Distribution of average and standard deviation before and after applying the "Ergonomic Checkpoints" and its effects on safety, health and working conditions in terms of percentage.

\begin{tabular}{|c|c|c|c|c|}
\hline \multirow{2}{*}{ 3Safety, health and working conditions } & \multicolumn{2}{|c|}{ Average (standard deviation) } & \multirow{2}{*}{ Average difference (standard deviation) } & \multirow{2}{*}{$P$ value } \\
\hline & Pre-application & Post-application & & \\
\hline Materials storage and handling & $83.70(10.15)$ & $89.23(9.37)$ & $5.52(10.55)$ & 0.002 \\
\hline Hand tools & $79.41(12.98)$ & $87.47(12.23)$ & $8.05(16.08)$ & 0.012 \\
\hline Productive machine safety & $78.99(16.02)$ & $87.67(14.54)$ & $8.67(20.15)$ & 0.019 \\
\hline Improving workstation design & $79.94(15.03)$ & $87.14(12.15)$ & $7.19(15.21)$ & 0.001 \\
\hline Lighting & $83.52(15.38)$ & $91.03(9.82)$ & $15.79(16.88)$ & 0.001 \\
\hline Premises & $80.84(12.33)$ & $89.23(10.58)$ & $8.39(2.05)$ & $<0.001$ \\
\hline Control of hazardous substances and agents & $75.25(15.25)$ & $91.05(9.82)$ & $15.79(16.88)$ & $<0.001$ \\
\hline Welfare facilities & $80.71(14.53)$ & $88.90(10.77)$ & $8.18(16.91)$ & 0.001 \\
\hline Work organization & $80.60(15.29)$ & $87.17(9.98)$ & $6.56(15.91)$ & 0.003 \\
\hline Total & $83.00(9.29)$ & $88.90(8.88)$ & $5.89(9.34)$ & $<0.001$ \\
\hline
\end{tabular}

Table 5: Comparison of the results of applying the checklist in two stages measured by the paired t-test.

next topics. The scores given to safety, health and working conditions increased significantly after the checkpoints were applied. Using a multiple-regression analysis, variables such as age, work experience and education were adapted in order to assign scores to the abovementioned factors after employing the "Ergonomic Checkpoints". The results showed that these variables had no significant effect, but that the score belonging to before applying the book caused a significant increase in the scores belonging to after applying the book: the postapplication scores increased by 0.3 for each one-score increase in the pre-application score, which is significant. Figure 2 shows the distribution of the total scores above 60 .

A comparison of results of applying the simple questionnaire before and after introducing the ergonomics checkpoints book

Table 6 presents the absolute and relative frequency distribution of the research units in terms of answers to the questionnaire's questions, which related to six different fields of research, technical sessions, checklists, learning methods, teamwork, and research continuation, before and after applying the checklists.

As for the relationship between the participant's responses to the questions, options "to a very high extent" and "to a high extent" were

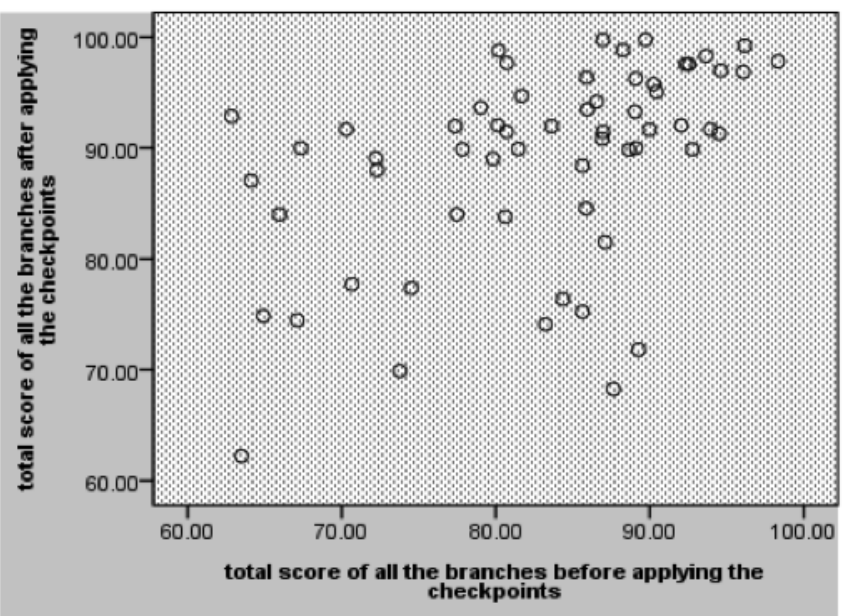

Figure 2: Distribution of the scores assigned to different branches of the "Ergonomic Checkpoints". 
Citation: Dastranj F, Helali F (2016) Implementing “Job Enrichment” with using Ergonomic Checkpoints in an 'Appreciative Way' at a Manufacturing Company in an Industrially Developing Country and its Meta-reflection. J Ergonomics 6: 172. doi:10.4172/2165-7556.1000172

Page 7 of 14

\begin{tabular}{|c|c|c|c|c|c|c|c|c|c|c|c|c|c|}
\hline \multirow{2}{*}{ Study } & & \multirow[b]{2}{*}{ Usefulness } & \multicolumn{5}{|c|}{ Pre-application (\%) } & \multicolumn{5}{|c|}{ Post-application (\%) } & \multirow[b]{2}{*}{$\begin{array}{c}P \\
\text { value }\end{array}$} \\
\hline & & & $\begin{array}{l}\text { To a } \\
\text { very } \\
\text { high } \\
\text { extent }\end{array}$ & $\begin{array}{l}\text { To a } \\
\text { high } \\
\text { extent }\end{array}$ & $\begin{array}{c}\text { To a } \\
\text { medium } \\
\text { extent }\end{array}$ & $\begin{array}{c}\text { To a } \\
\text { low } \\
\text { extent }\end{array}$ & $\begin{array}{l}\text { To a } \\
\text { very } \\
\text { low } \\
\text { extent }\end{array}$ & $\begin{array}{l}\text { To a } \\
\text { very } \\
\text { high } \\
\text { extent }\end{array}$ & $\begin{array}{l}\text { To a } \\
\text { high } \\
\text { extent }\end{array}$ & $\begin{array}{l}\text { To a } \\
\text { medium } \\
\text { extent }\end{array}$ & $\begin{array}{l}\text { To a } \\
\text { low } \\
\text { extent }\end{array}$ & $\begin{array}{l}\text { To a } \\
\text { very } \\
\text { low } \\
\text { extent }\end{array}$ & \\
\hline \multirow{6}{*}{ Research } & 1 & $\begin{array}{l}\text { The research-related } \\
\text { explanations were clear to me }\end{array}$ & 10.2 & 47.5 & 35.6 & 6.8 & 0 & 15.3 & 64.4 & 20.3 & 0 & 0 & $P=0.012$ \\
\hline & 2 & $\begin{array}{c}\text { Different stages of the research were clear } \\
\text { to me }\end{array}$ & 11.9 & 49.2 & 32.2 & 6.8 & 0 & 13.6 & 61 & 23.7 & 1.7 & 0 & $P=0.113$ \\
\hline & 3 & The research was useful for me & 39 & 44.1 & 8.5 & 5.1 & 3.4 & 47.5 & 32.2 & 18.6 & 1.7 & 0 & $P=0.46$ \\
\hline & 4 & $\begin{array}{l}\text { I am glad of choosing this } \\
\text { research }\end{array}$ & 33.9 & 33.9 & 20.3 & 10.2 & 1.7 & 35.6 & 42.4 & 18.6 & 0 & 1.7 & $P=0.216$ \\
\hline & 5 & $\begin{array}{l}\text { I am satisfied with the managers' } \\
\text { participation in the research }\end{array}$ & 32.2 & 45.8 & 15.3 & 5.1 & 1.7 & 35.6 & 47.5 & 11.9 & 0 & 3.4 & $P=0.427$ \\
\hline & 6 & $\begin{array}{l}\text { I am glad that the company } \\
\text { has cooperated with the research project }\end{array}$ & 45.8 & 32.2 & 11.9 & 8.5 & 1.7 & 52.5 & 33.9 & 11.9 & 0 & 0 & $P=0.113$ \\
\hline \multirow{4}{*}{ Sessions } & 8 & $\begin{array}{l}\text { The sessions aimed at discussing the } \\
\text { checklists were useful for me }\end{array}$ & 11.9 & 35.6 & 44.1 & 8.5 & 0 & 16.9 & 49.2 & 33.9 & 0 & 0 & $P=0.012$ \\
\hline & 9 & $\begin{array}{l}\text { Having got required information in the } \\
\text { sessions, I have more knowledge about } \\
\text { work-related problems now }\end{array}$ & 16.9 & 42.4 & 33.9 & 6.8 & 0 & 39 & 45.8 & 15.3 & 0 & 0 & $P=0.000$ \\
\hline & 10 & $\begin{array}{l}\text { Holding such meetings could help solve } \\
\text { work-related problems }\end{array}$ & 40.7 & 32.2 & 23.7 & 1.7 & 1.7 & 44.1 & 39 & 11.9 & 5.1 & 0 & $P=0.433$ \\
\hline & 11 & $\begin{array}{l}\text { The length of time allocated to the technical } \\
\text { sessions was sufficient }\end{array}$ & 3.4 & 10.2 & 61 & 15.3 & 10.2 & 5.1 & 18.6 & 54.2 & 18.6 & 3.4 & $P=0.103$ \\
\hline \multirow[b]{2}{*}{ Checklist } & 12 & The checklist's topics were clear to me & 10.2 & 39 & 44.1 & 6.8 & 0 & 16.9 & 64.4 & 16.9 & 1.7 & 0 & $P=0.001$ \\
\hline & 13 & $\begin{array}{c}\text { Standard checklists of this type could help } \\
\text { solve my work-related problems }\end{array}$ & 30.5 & 33.9 & 28,8 & 5.1 & 1.7 & 30.5 & 42.4 & 22 & 5.1 & 0 & $P=0.455$ \\
\hline \multirow{5}{*}{$\begin{array}{l}\text { Learning } \\
\text { Methods }\end{array}$} & 14 & I am familiar with the term "ergonomics" & 20.3 & 40.7 & 32.2 & 5.1 & 1.7 & 37.3 & 52.5 & 10.2 & 00 & 0 & $P=0.000$ \\
\hline & 15 & I have basic knowledge about ergonomics & 3.4 & 3.9 & 37.3 & 16.6 & 6.8 & 18.6 & 66.1 & 15.3 & 0 & 0 & $P=0.000$ \\
\hline & 16 & $\begin{array}{l}\text { The volume of work-related problems are } \\
\text { tangible and obvious for me thanks to the } \\
\text { information provided by the checklist }\end{array}$ & 8.5 & 55.9 & 28.8 & 3.4 & 3.4 & 15.3 & 66.1 & 18.6 & 0 & 0 & $P=0.011$ \\
\hline & 17 & $\begin{array}{c}\text { I can be more useful in solving work-related } \\
\text { problems thanks to the information provided } \\
\text { by the checklist }\end{array}$ & 18.6 & 47.5 & 28.8 & 1.7 & 1.7 & 20.3 & 45.8 & 27.1 & 0 & 6.8 & $P=0.738$ \\
\hline & 18 & $\begin{array}{c}\text { It is good that workers, supervisors and } \\
\text { managers are all involved in discussing and } \\
\text { improving safety, health and working } \\
\text { conditions }\end{array}$ & 50.8 & 24.5 & 18.6 & 3.4 & 1.7 & 44.1 & 42.8 & 10.2 & 3.4 & 0 & $P=0.712$ \\
\hline \multirow{3}{*}{$\begin{array}{l}\text { Team } \\
\text { Work }\end{array}$} & 21 & I like teamwork & 39 & 37 & 22 & 0 & 1.7 & 44.1 & 44.1 & 8.5 & 1.7 & 1.7 & $P=0.276$ \\
\hline & 22 & This kind of teamwork is useful at my work & 22 & 27.1 & 37.3 & 10.2 & 3.4 & 32.3 & 37.3 & 37.1 & 1.7 & 1.7 & $P=0.027$ \\
\hline & 23 & $\begin{array}{l}\text { Ergonomics teamwork could help identify and } \\
\text { solve problems in a better way at my work }\end{array}$ & 39 & 40.7 & 16.9 & 1.7 & 1.7 & 39 & 47.5 & 13.6 & 0 & 0 & $P=0.433$ \\
\hline
\end{tabular}

Table 6: Absolute and relative distribution of the research units in terms of answering the research questions before and after applying the checklists.

assigned high scores, the option "to a medium extent" was assigned a high score, and options " to a low extent" and "to a very low extent" were assigned low scores. The results were collected and analyzed using Wilcoxon signed-rank test and McNemar's test.

The Wilcoxon signed-rank test showed no significant relationship between the responses provided in the first stage and the ones provided in the second stage. The "Ergonomic Checkpoints" has not been effective in this regard since the participants had earned required knowledge about the research during the sessions.

As for the sessions, checklists and learning methods, the statistical test showed a significant relationship between the responses provided in the first stage and the ones provided in the second stage, meaning that the application of the "Ergonomic Checkpoints" has been effective in this connection.

With respect to teamwork, the statistical test showed no significant relationship between the responses provided in the first stage and the ones provided in the second stage since the participants had earned a high score from the very beginning.
As for research continuation, the McNemar's test showed no significant relationship between the responses provided in the first stage and the ones provided in the second stage, because the participants had earned a high score from the very beginning and 96.4 percent of the respondents had given a positive response in the first stage, with the remainder giving a positive response in the second stage.

The general perception of the participants from the questionnaire's open-ended questions in the second stage (after applying the checkpoints) is indicative of the following points:

- The need for considering the benefits of both the workers and the organization when improving working conditions.

- The need for cooperation and teamwork to promote ergonomics.

- The need for paying attention to ergonomics science and technology.

- The need of for the support and participation of the managers and staff in applying ergonomics in practice. 
- The need for observing safety, health and ergonomic rules through paying attention to practical learning aimed at solving work-related problems.

- The need for regular cooperation with research activities and providing scientific support to the company

- The need for regular cooperation and support on the part of the managers and paying attention to applicable research in the company.

- The need for cooperation has been emphasized by the participants: some $98.2 \%$ percent of the participants in the first stage and 100 percent of them in the second stage called for continuing the research.

Besides, during the technical sessions it was observed that some of the participants, including the workers, were exposed to the new learning method (learning in action) for the first time. Some of them experienced stress due to their low levels of education and the presence of their managers and supervisors, but they realized after a while that the atmosphere of the sessions had made it possible for each participant to put forth their ideas in a simple language by relaying on their experiences and basic knowledge (tacit knowledge), reading them from a paper or narrating what they had learned from the checklists. As a result, they felt more relaxed at the sessions and presented their viewpoints with greater peace of mind.

\section{Results of organizational documents and minutes of hse division during the last three years}

All the personnel underwent periodical check-ups during the year and each of them had a health record completed by the company's occupational medicine physician and occupational health expert. Based on the existing documents, the workers had complained about back pain and wrist pain on numerous occasions. A list of safety and health issues had been raised during the meetings of the company's health and safety committee according to the meetings' minutes. The minutes showed that some of the activities carried out over the recent two years to solve work-related problems in the company included: Conducting ergonomics evaluation for the packing personnel based on the RULA method, providing stools, making ergonomic worktables, providing wheelbarrows for displacing capsules, evaluating workstation posture, providing educational and sports CDs on backache prevention for all the personnel and CDs on special exercises for computer operators, providing more comfortable chairs for those who had to sit at work, providing trolleys and jumbo machines to the restaurant to be used for displacing materials and heavy pots, making trolleys, providing electronic lift trucks to the warehouse to be used for lifting goods to higher heights, purchasing jumbo machines for different production units, building loading platforms for all the warehouses to facilitate displacement of goods, enforcing health regulations for manual material handling, and purchasing electric lift trucks for the warehouses to be used for lifting goods to lower heights.

\section{Results of the project's evaluation}

Results of the workshop evaluation with the participants: During the evaluation workshop, the most important things mentioned by the participants in answer to the question "what have you learned from the research project?" included: The need for cooperating with the research and resuming it as it contributes to improving productivity, learning technical skills, cooperation and teamwork, examination and identification of risks at the workplace through achieving work-related information, familiarity with work-related problems and solving them with the cooperation of the workers, learning how to deal with workrelated problems, familiarity with relevant standards, cooperation with the managers, learning to mix experiences and techniques at work, adopting a deeper approach toward work-related issues, learning ergonomics as an applicable science, developing a new viewpoint about how to do the job and identify problems at work, cooperating in doing the job and using the experiences of the colleagues, familiarity with different departments of the company and their work-related issues, taking responsibility at work and in cooperation with others, interest in the job through satisfaction with cooperation, effective planning at work through cooperation, contemplation in early stages and planning and acting in later stages, familiarity with participatory methods aimed at improving health and safety at work, interaction with others, reducing work-related costs, and alike.

In addition, the participantscreated six workinggroupsand discussed a number of questions on their participatory ergonomics process (including "Why?" and "How?" trust in cooperation; involvement in cooperation: motives for cooperation; expanding technical and social skills; the need for adopting a participatory ergonomics approach; learning and doing the job safely during the evaluation workshop that its interpretation is indicative of the following points: Realizing the need for building trust through participation in the learning process and increasing productivity, Realizing the need for learning from each other and interacting with the managers and other staff, Realizing the need for creating the feeling of possession and accountability at work, Realizing the need for paying attention to competence, creating sound and healthy organizations, using the capabilities of others and leaning from them, learning in action, Realizing the need for interaction among the employees (managers, supervisors, workers), learning in action, involvement aimed at cooperation and coordination through creating teamwork committees, contacting scientific centers and Realizing the need for developing proper methods of doing the job coupled with mutual respect, as well as the need for learning from each other.

Results of the interviews as reflection learning from some participant: Table 7 presents the results of interviews with the participants, including one supervisor, a worker and an occupational health expert, about the procedure and process of the research project.

Result of the technical top managers session: During the meeting with the top technical managers, a report on the research work was presented and its results were discussed. The managers raised their questions and became familiar with the goals of the technical sessions and the concept of learning in action properly. They also admitted and appreciated that the materials were easy to understand and that they could help each other to easily understand them. Even one of the top managers taking part in the research project, a person who had agreed to permit the research, stated that he had primarily thought that ergonomics had nothing to do with safety and health, but that he had changed his approach toward personnel health after taking part in the technical sessions, filling out the checklists and collecting feedback in two stages. He also said that the research has increased his knowledge and that of the personnel about correcting working conditions, expressing satisfaction over the possibility of integrating safety, health and working conditions in the working environment and calling for the continuation of the process for the entire personnel.

\section{Discussion and Conclusion}

The results and interpretations are discussed from the perspectives of the following: "the definition of a pre-systemic intervention work", "the research model", "the strategy for the learner at the Centre", "using power participatory ergonomics process as a tactic of polling", and "reflection learning as the learning of reflection". 
Citation: Dastranj F, Helali F (2016) Implementing “Job Enrichment” with using Ergonomic Checkpoints in an 'Appreciative Way' at a Manufacturing Company in an Industrially Developing Country and its Meta-reflection. J Ergonomics 6: 172. doi:10.4172/2165-7556.1000172

Page 9 of 14

\begin{tabular}{|c|c|c|}
\hline Interviewee & Interview results & Interpretation \\
\hline $\begin{array}{l}\text { One supervisor, holding } \\
\text { B.Sc. degree, } 30 \text { - years } \\
\text { old, } 5 \text { years of service in } \\
\text { the Company }\end{array}$ & $\begin{array}{l}\text { Before taking part in the sessions, I knew little about ergonomics. I had just } \\
\text { got some information about it through posters and mottos. When I was invited } \\
\text { to take part in the sessions, I was initially reluctant to do so because of the } \\
\text { volume of my duties and responsibilities, but I became interested in it after } \\
\text { I took part in the first session and found out that it offered a new learning } \\
\text { method. All the personnel, including managers, supervisors and workers, } \\
\text { equally participated in the learning process, something that encouraged their } \\
\text { colleagues to take part in the sessions eagerly. So all the participants were } \\
\text { like members of the same family and each one offered what they had learnt. } \\
\text { The participants gradually lost their stress, and the materials presented during } \\
\text { the sessions were easy to understand. The evaluation workshop was also } \\
\text { useful and valuable for me. During the technical sessions, I became familiar } \\
\text { with the real meaning of ergonomics and realized that it has greatly affected } \\
\text { every aspect of my life, including my personal life. Now, I pay attention to } \\
\text { everything that takes places at work and teach my Subordinates how to do } \\
\text { their work properly. I also pay more attention to lighting, volume and size of } \\
\text { goods, stairs, slope areas, lines, substance handling, discipline, elderly people, } \\
\text { pregnant women, personnel participation, personnel viewpoints, etc. now }\end{array}$ & $\begin{array}{l}\text { Positive experiences and job enrichment have been products } \\
\text { of bottom-up ergonomic approach (participatory ergonomics), } \\
\text { learning in action and also reflective learning. When research is } \\
\text { focused on a company and its personnel, the people learn from } \\
\text { each other in a better way and have better access to their technical } \\
\text { and social skills. They also use those skills in their daily life and } \\
\text { learn how to use them subsequently }\end{array}$ \\
\hline $\begin{array}{l}\text { A worker } \\
\text { who was primarily } \\
\text { reluctant to take part in } \\
\text { the technical sessions } \\
\text { holding Diploma } \\
\text { degree, 28- years old, } 8 \\
\text { years of service }\end{array}$ & $\begin{array}{l}\text { I personally was reluctant to present my viewpoint in front of my colleagues, but } \\
\text { I was persuaded to do so after the researcher talked to me. I also gained self- } \\
\text { confidence when I saw that other participants with lower education presented } \\
\text { the checklists in a narrative way in the presence of all the participants. So, I } \\
\text { got interested in the learning method of the sessions. } \\
\text { I had no information about ergonomics before the sessions, but I gained } \\
\text { knowledge about it during the sessions and changed my approach toward } \\
\text { my work, colleagues, equipment, lighting, etc. Now, I try to see everything } \\
\text { through participatory ergonomics. During the evaluation workshop, I realized } \\
\text { that I had already known many of the related issues, but did not know how to } \\
\text { recount them. The sessions were too short. The sessions will be more useful } \\
\text { and understandable if they resume and be held practically at workplace }\end{array}$ & $\begin{array}{l}\text { Implied knowledge about how mutual respect, building confidence, } \\
\text { and increasing motivation through learning in action and deliberate } \\
\text { learning could contribute to improving technical and social skills }\end{array}$ \\
\hline $\begin{array}{l}\text { The company's HSE } \\
\text { expert holding B.Sc. } \\
\text { degree, 39- years old, } \\
3 \text { years of service in the } \\
\text { Company }\end{array}$ & 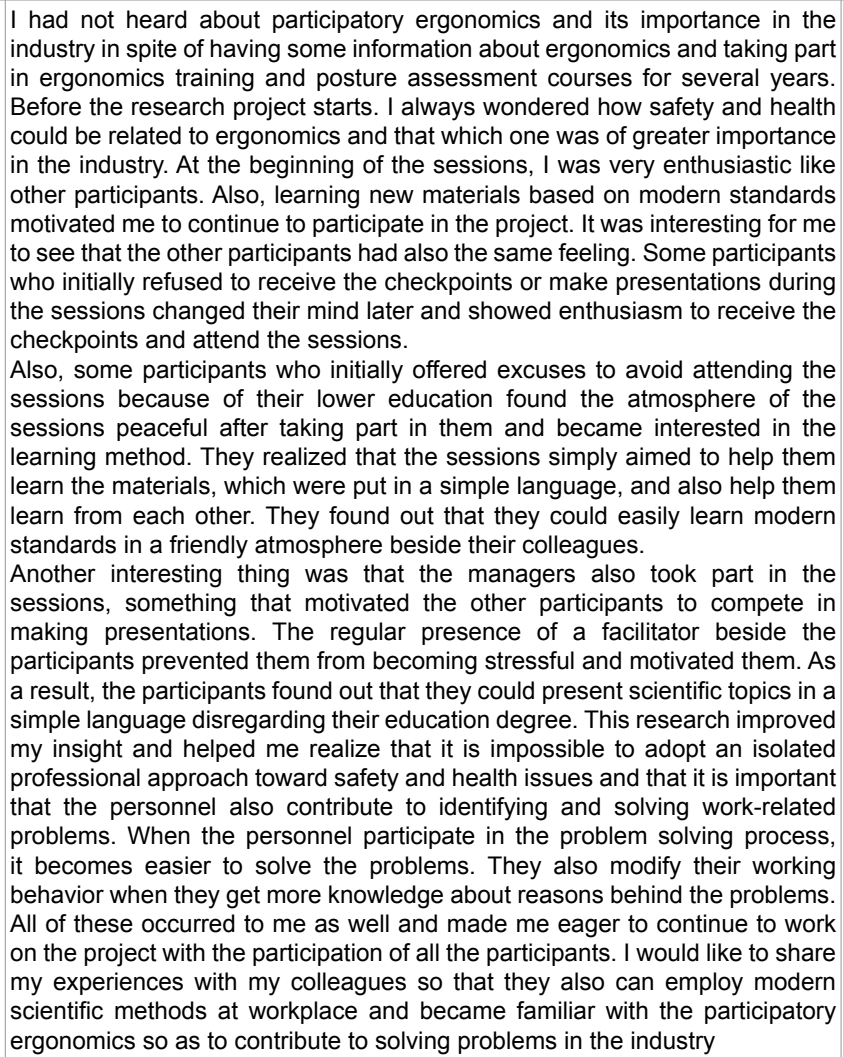 & $\begin{array}{l}\text { le } \\
\text { The need for the } \\
\text { participatory ergonomics' assistance to the industry sector of } \\
\text { developing countries such as Iran, } \\
\text { The role of action learning, intentional learning and active learning, } \\
\text { Interaction between different levels of the organization through } \\
\text { setting common goals and determining joint activities, Involvement } \\
\text { aimed at participation and cooperation in solving work-related } \\
\text { problems on the part of the personnel, } \\
\text { Reflective learning (learning of reflection) could improve the living } \\
\text { condition of the personnel and make them grateful. As a result, the } \\
\text { personnel will be motivated to promote ergonomics in practice to } \\
\text { share experiences with other colleagues }\end{array}$ \\
\hline
\end{tabular}

Table 7: Feedback learning and its interpretations for three participants, including one supervisor, a worker and a safety \& health expert of the company, taking part in the research project.

\section{The definition of a pre-systemic intervention work}

As it is shown in Figure 3, a frame has been designed to define the pre-systemic ergonomics intervention work process prior to using the Ergonomic Checkpoints of ILO (2010). This is a concept of empowerment as process [35]. It represents a key factor which requires that employees are firstly empowered if they are expected it positively empower each other.

Based on the empirical evidences from this study, integrating the aforementioned factor coupled with the creation of a team of 


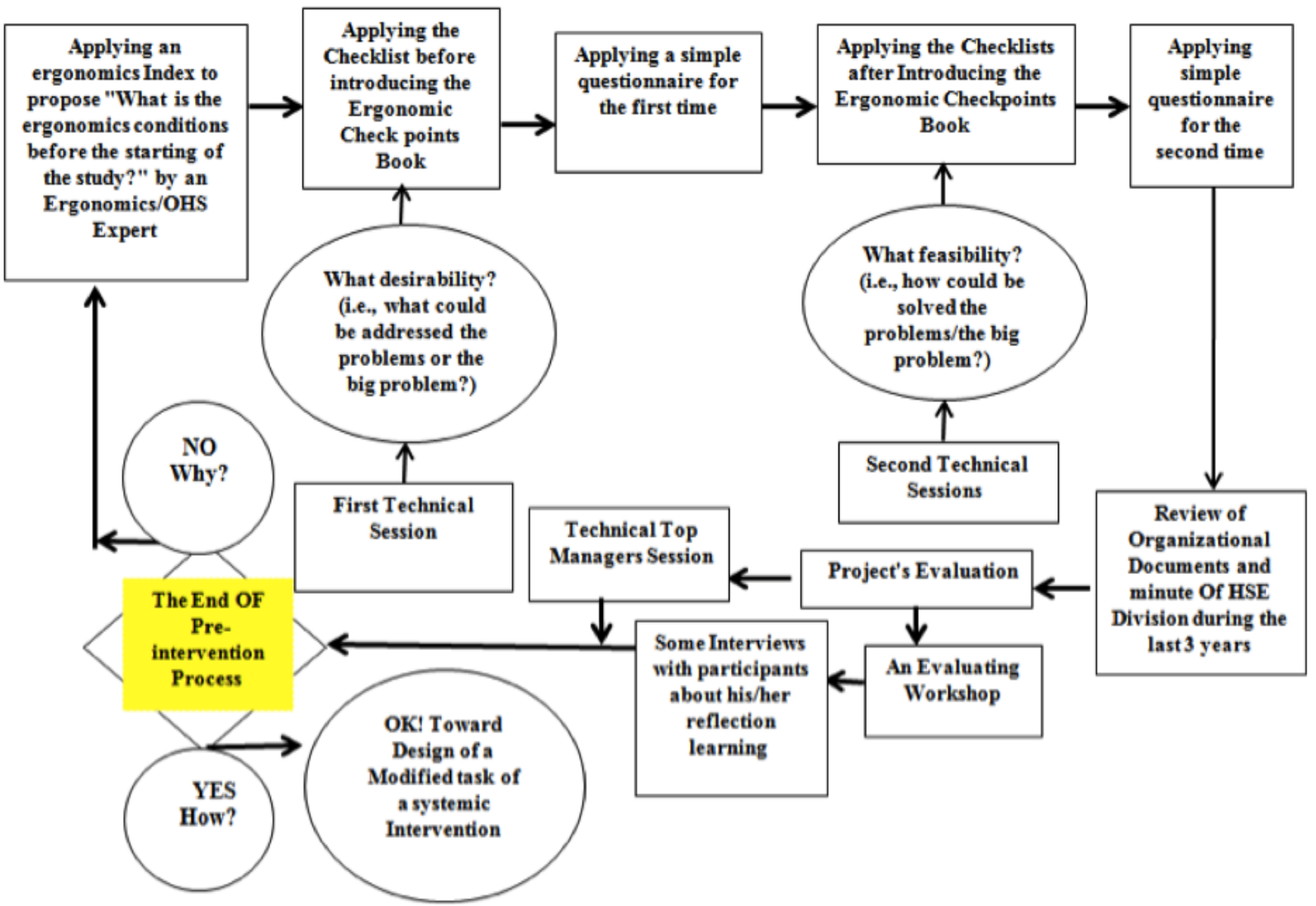

Figure 3: Frame of a phase method pre-systemic ergonomics intervention work process [7].

facilitators (the authors were the internal and external facilitators), resulted in a 0.3 percent improvement in the technical capabilities of the participants, as well as an improvement in their social skills and interest in participation. The key findings were made through intentional learning on how the participants could be empowered to self-improve their technical and social skills, based on the interactive approach used in the systemic pre- ergonomics intervention work process.

\section{The research model}

The findings in this study are signified by the behavioral cybernetics principles introduced by smith and smith [37,42]. Behavioral cybernetics deals with human behavior as a self-autonomous and closed-loop feedback control process and focuses on feedback relations between individuals and the environment. The research model [36] indicates that effective internal cooperation programs could be developed by implementing processes designed for action, feedback and feedback control in workplace (Figure 4).

Because the model [36,37] proves that learning, action and control expands among participants over time, changing cooperation programs (involvement aimed at cooperation and coordination in this research) from programs externally regulated by the external expert (facilitator) into the ones internally regulated by organization members (participants in this research) occurred gradually.

In this study, the participants practically examined the checklists using their basic knowledge and/or previous experiences during the technical sessions held in the first stage. They also learned the materials in detail for a certain period of time, and through the use of the ergonomic checkpoints and group interaction during the technical sessions held in the second stage. Following that, the participants were exposed to a deeper level of learning and vigilance, and played an active role in learning (active learning) through the creation of an atmosphere for them to learn from each other during the technical sessions. The participants witnessed an increase in their mental growth, managed to make better use of the checklists in the second stage and observed changes in their knowledge and performance with regard to identifying risks at work (change in action), thanks to the materials they consciously learnt from the standard checklists in the first stage, their better social interactions during the technical sessions, and the role of the internal and the external facilitators.

Feedback on active participation of the participants in the research were obtained by asking them to fill out questionnaires in the first and second stages, holding an evaluation workshop and using a scaffolding method provided by the external facilitator to discuss topics raised in individual and group discussions, all of which are elements of cooperative ergonomics in the whole research process. The feedback provided a type of job enrichment outcome for the participants, thanks to topics covered and analyzed by the questionnaires and the evaluation workshop. Also, some of the participants (including manager, supervisor and worker) as well as the company's HSE expert were interviewed and feedback on their active participation in the study was obtained (active participation with feedback). The participants' attitude as well as their perception of different aspects of the workplace, such as the importance of research, checklists, technical sessions, learning methods, teamwork, and evaluation workshops changed after they filled out the questionnaires in the first and second stages (change in perception). Each stage of the process and the final assessment strongly contributed to forming active closed-loop cybernetics behavior. Learning, action and action control as well as continuous learning expanded 


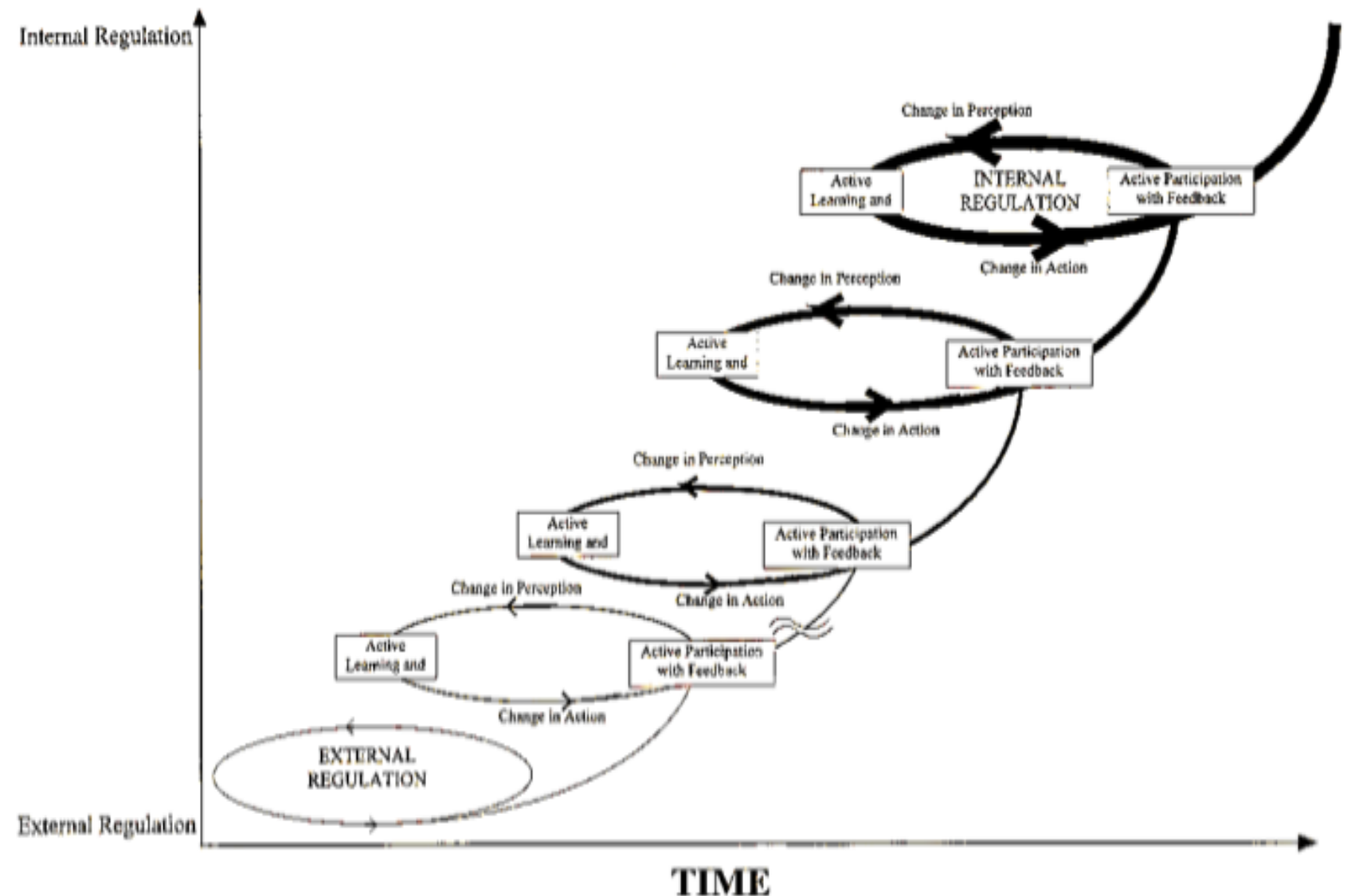

Figure 4: Research model based on Smith and Smith [37] and adapted from Haims and Caryon [36].

among the participants during a certain period of time, and the learning process and implementation of participatory programs changed from programs regulated internally by the facilitators and available instruments to externally regulated programs, leading to mental growth and active learning among organization members (participants) subsequently.

\section{The strategy for the learner at the centre}

Wood et al. [43] expanded Vygotsky's theory and introduced the scaffolding concept based on which adults help children to develop their cognitive skills. An important aspect of scaffolding is that support for children gradually diminishes as their self-confidence increases. There are different types of learning theories, but the one proposed by this research is introduced as a guideline that enables individuals to present what they know through the use of checklists. But when checkpoints were used in this research, the participants had to deliberately learn the materials, employ their capabilities and promote their skills through the guidance and encouragement of the internal facilitator and their colleagues. Therefore, the first and the second authors of this article have played the role of scaffolding for the participants and have helped them pass through ZDP (See Figure 5, by designing the procedure, providing resources and discussions, and creating an atmosphere for deliberate learning [38]. A total of $102 \mathrm{~h}$ of research training course for the first author was conducted by the second author. The first author (internal facilitator) played a role in a type of special scaffolding covering deliberates learning and learning in action to contribute to her own job enrichment.
The using power participatory ergonomics process as a tactic of polling

The model of participatory ergonomics introduced by Haines and Wilson [28] shows the principles of participatory ergonomics used by individuals in designing and analyzing work-related problems, through the employment of different types of involvement approaches introduced by Brown $[39,40]$, as well as the use of instruments and techniques, such as checklists, checkpoints, questionnaires, evaluation workshop, interviews. This research exposed the participants to the participatory ergonomics process as an effective tactic. The participants observed an improvement in their technical and social capabilities and skills through the use of checklists and checkpoints and through taking part in technical sessions, all of which created an atmosphere of learning for them.

The statistical results presented in Tables 5 and 6; Figures 1 and 2 as well as the results of the evaluation workshop showed that; putting trust in participation in each stage of the research, which was associated with continuous learning, has further motivated the participants and encouraged them to offer a significant level of cooperation, start learning from each other, develop the capability to present suggestions to the organization, and call for applying the results of the research during the execution of the pre-ergonomic intervention work process.

Involvement aimed at cooperation and participation took place based on Brown's three participants' involvement ways, two of which were illustrated in Figure 6, i.e., parallel suggestion involvement and 


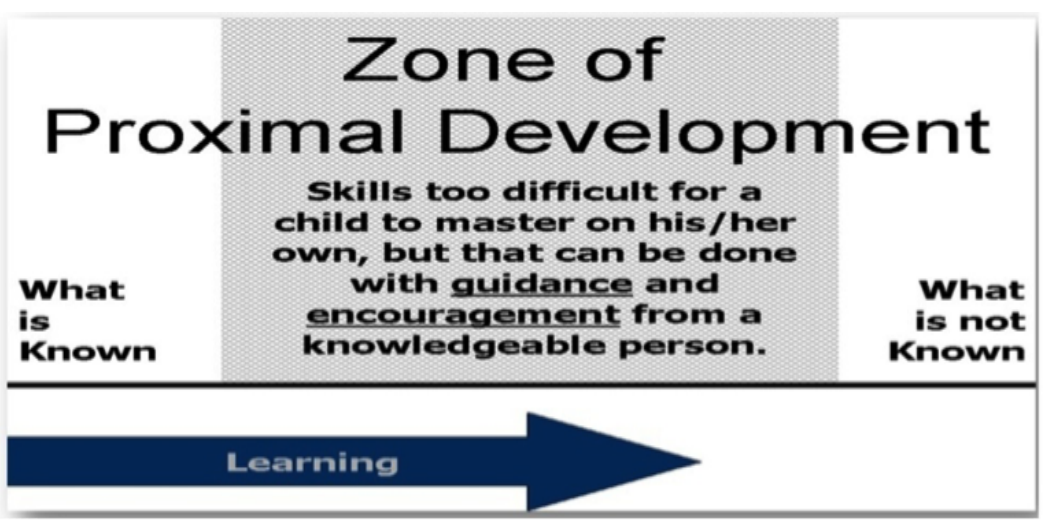

Figure 5: The zone of proximal development.

\section{Nature of Participatory Ergonomics}

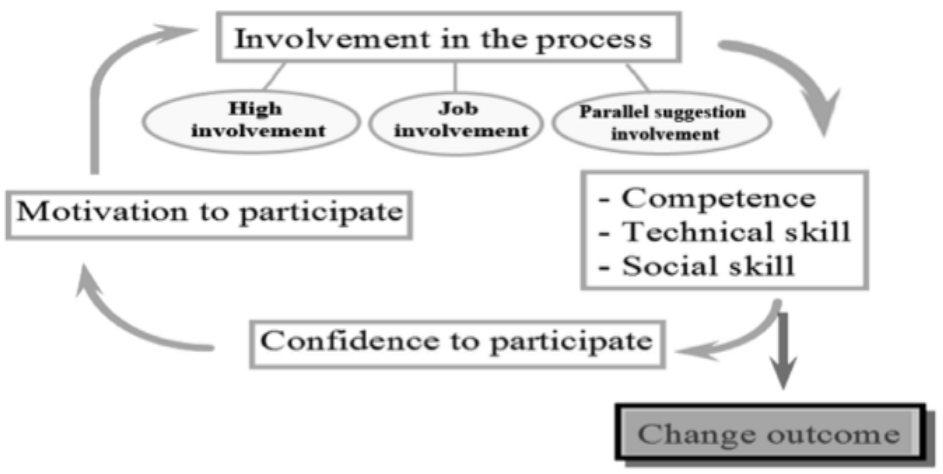

Figure 6: The nature of a participatory ergonomics cycle (Source adapted from, Haines and Wilson [28]; Brown [39,40].

job involvement. Based on these tactics, the participants presented their viewpoints in different situation in order to better understand relevant issues geared towards improving the safety, health and working condition in the organization. Also, the team of facilitators helped them improve their merits (technical and social skills), create the culture of cooperation, solve their work-related problems and approach safety, health and ergonomics as a whole.

The best type of involvement that occurred in this research was involvement aimed at cooperation and job involvement [6], which materialized in the form of an opportunity and idea for job enrichment. It means that by creating an atmosphere of learning, working with the participants and the company, seeking assistance from the facilitators and employing proper instruments, the participants' learning capabilities improved and led to their deliberate learning with feedback. As a result, the participants shared knowledge with each other and were able to fill out the checklists and understand them in a better way. This is a manifestation of continuous learning in the participatory ergonomics process and a type of reflective learning [11].

Lawler Edward [41] explains that one reason behind attaching importance to personnel participation in today's world is that the personnel are more specialized in their own job and can solve existing problems. He points out that most individuals tend to control the whole work, something that leads to participation in handling information, knowledge, compensation, or top-down authority in the organization. In the participatory ergonomics approach, ergonomists and nonspecialist individuals should also contribute to solving work-related problems. Ensuring improved motivation and job involvement in the participative ergonomics approach in identifying and solving problems related to safety, health and working conditions helped the participants to interact with the internal and external facilitators.

\section{A concluding thought}

Factors which contributed to the success of this research include the following: 1) Awakened need of change (which materialized through employing ILO's "Ergonomic Checkpoints" and appreciating the need for approaching understanding in the deep health, safety, and ergonomics and the working condition as a whole in this research); 2) Continuous learning (which materialized through the use of strategies, tactics and instruments such as checklists, checkpoints, and questionnaires as well as through learning from each other in the technical sessions, the reflective learning and the participants' feedbacks; 3) Integrating the afore-mentioned factors by creating a team of facilitators, which resulted in a 0.3 percent improvement in the technical capabilities of the participants and improved their social skills and their interest in participation in the company during this research work; 4) 'A Proposed Model for the Appreciative Inquiry and Way' could be formulated as a Meta-reflection in Figure 7. 
Citation: Dastranj F, Helali F (2016) Implementing “Job Enrichment” with using Ergonomic Checkpoints in an 'Appreciative Way' at a Manufacturing Company in an Industrially Developing Country and its Meta-reflection. J Ergonomics 6: 172. doi:10.4172/2165-7556.1000172

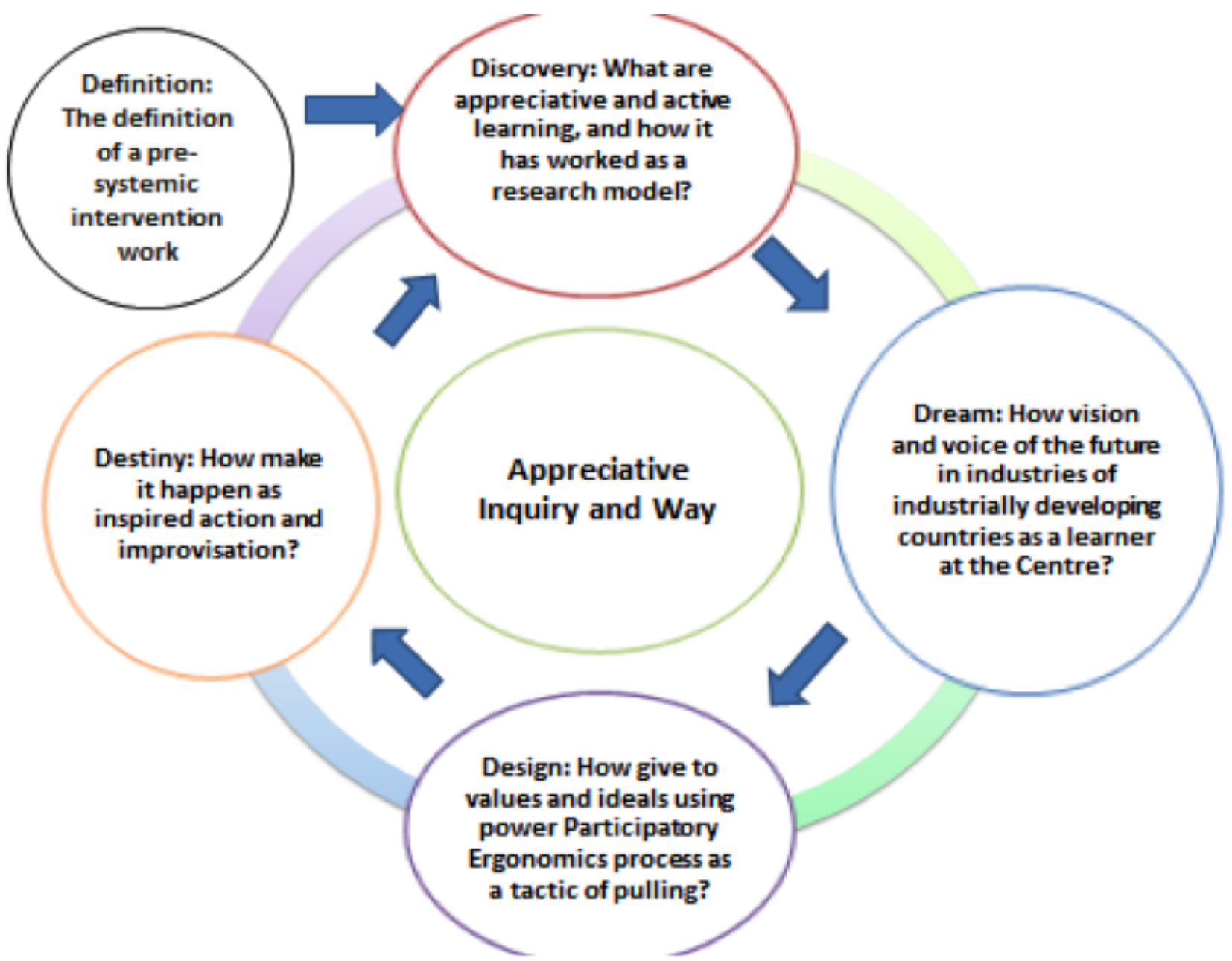

Figure 7: The proposed model for the appreciative inquiry and way as the meta-reflection.

It is a necessity that such applicable research will be financially supported by industrial managers and health policymakers in IDCs so that jobs are further enriched to contribute to improving health, safety, and working conditions and consideration of the integrating "Ergonomics, Heath, Safety" at workplaces and also the improvement of livelihood in the IDC's industries.

\section{References}

1. Kogi K (2001) Basic Ergonomics Checklists. In: Karwowski W (ed.) International Encyclopedia of Ergonomics. Florence, KY, USA. Taylor, pp: 1747-1750.

2. Kogi K (2007) Action-oriented use of ergonomic checkpoints for health work design in different setting. J Human Ergol 36: 37-43.

3. Kogi K (1995) Participatory ergonomics that builds on local solutions. J of Hum Ergon 24: 37-45.

4. Niu S (2010) Ergonomics and occupational safety and health: An ILO perspective. App Ergon 41: 744-753.

5. Budnick P, Kogi K, O'Neill D (2012) Examples of Practical Ergonomics in Industrially Developing Countries. Ergonomics Design 20: 5-11.

6. Helali F (2008) Developing an Ergonomics Intervention Technique Model to Support the Participatory Ergonomics Process for Improving Work Systems in Organizations in an Industrially Developing Country and its 'Meta-Reflection. Lulea University of Technology Department of Human Work Sciences Division of Industrial Work Environment.
7. Helali F, Abdollahpour N (2014) How could you implement 'Awakened Need of Change' for the applying ergonomics to work system in Industrially Developing Countries? In: Broberg O, Fallentin N, Hasle P (eds.) Copenhagen, Denmark, pp: 51-257.

8. Karwowski W (2001) International Encyclopaedia of Ergonomics and Human Factors. Taylor and Francis.

9. Hörte SA (2006) Styles of research in ergonomics: Halmstad University Sweden and SMARTA/National Institute for Working Life. Paper presented at the $38^{\text {th }}$ Annual NES 2006 Congress, 24-27 September, Hämeenlinna.

10. McGill I, Beaty L (2001) Action learning: a guide for professional, management and educational development ( $3^{\text {rd }}$ edn.) London: Rogan.

11. Helali F (2012) How could you use the ergonomics know-how transfer management to enhance human working for sustainable improvements in industrially developing countries? Work 41: 2730-2735.

12. Helali F (2015) Building Taxonomy Knowledge 'Systemic Ergonomics Intervention Work' - a Product joining up practice with theory in an Industrially Developing Country and its 'Meta-Reflection'. Melbourne, pp: 9-14.

13. Hendrick HW (2002) Other Methods for Assessing Work Systems, In Hendrick HW and Kleiner BM (eds.) Macroergonomics: Theory, methods and applications. New Jersey: Lawrence Erlbaum, pp: 97-110.

14. Hendrick HW, Kleiner Brian M (2002) Macroergonomics Theory, Methods, and Applications book, Lawrence Erlbaum Associates, Publishers Mahwah, New Jersey London 19. 
Citation: Dastranj F, Helali F (2016) Implementing “Job Enrichment” with using Ergonomic Checkpoints in an 'Appreciative Way' at a Manufacturing Company in an Industrially Developing Country and its Meta-reflection. J Ergonomics 6: 172. doi:10.4172/2165-7556.1000172

15. Helali F (2009) The Ergonomics 'Know-how' Transfer Models to IDC's Industries (Concept, Theory, Methodology, Method, Technique), LAMBERT Academic Publishing $A G$ and $\mathrm{Co}, \mathrm{KG}$, UK and USA.

16. ILO (2010) Ergonomics Checkpoints, Practical and easy-to-implement solutions for improving safety, health and working conditions. Geneva, International Labour Office.

17. Helali F (2009) Using 'Ergonomic Checkpoints' to support the participatory ergonomic intervention in an Industrially Developing Country (IDC) - a Case Study published in JOSE. 15: 325-337.

18. Imada AS (1986) Is participatory ergonomics appropriate across culture? Trends and future criteria, Proceeding of the Human Factors Society 30th Annual Meeting Human Factors Society, Santa Monica, CA, pp: 1107-1109.

19. Imada AS, Nagamachi M (1995) Introduction to Participatory Ergonomics. Int $J$ of Indu Ergon 15: 309-310.

20. Eerd DV, Cole D, Irvin E, Mahood Q, Keown K, et al. (2010) Process and implementation of participatory ergonomic interventions: a systematic review. Ergonomics 53: 1153-1166.

21. Scott $P$ (2009) Ergonomics in Developing Regions: Needs and Applications. CRC Press.

22. Vink P, Imada AS, Zink K (2008) Defining stakeholder involvement in participatory design processes. App Ergon 39: 519-526.

23. Hignett S, Wilson JR, Morris W (2005) Finding ergonomic solutions-participatory approaches. Occup Med 55: 200-207.

24. Wilson JR, Haines HM (2001) Participatory ergonomics. In: Karwowski W (ed.) International encyclopedia of ergonomics and human factors. London, UK, Taylor and Francies, pp: 1282-1286

25. Kuorinka I (1997) Tools and means of implementing participatory ergonomics. Int J Indu Ergon 19: 267-227.

26. Wilson JR, Haines HM (1997) Participatory ergonomics. In: Salvendy G (ed.) Handbook of human factors and ergonomics $\left(2^{\text {nd }}\right.$ edn.) New York, NY, USA Wiley, pp: 490-513

27. Haines $H$, Wilson JR, Vink $P$, Koningsveld $E$ (2002) Validating a framework for participatory ergonomics (the PEF). Ergonomics 45: 309-327.

28. Haines H, Wilson JR (1998) Development of a framework for participatory ergonomics Contract Research Report 174, HSE, Sudbury.

29. Cotton JL (1993) Employee Involvement. Methods for Improving Performance and Work Attitudes. Sage, Newbury Park.
30. Stanton N, Hedge A, Brookhuis K, Salas E, Hal Hendrick (2005) Handbook of Human Factors and Ergonomics Methods, Boca Raton London New York Washington, DC

31. Hendrick HW, Kleiner BM (2001) Macroergonomics, an introduction to work system design. Human Factors and Ergonomics Society, USA.

32. Imada AS (1991) The rationale and tools of participatory ergonomics. In: Noro K, Imada (edn), Participatory ergonomics. London, UK Taylor and Francise.

33. Helali F, Dastranj F (2014) How could you use the ergonomic checkpoints for job enrichment in an 'appreciative way' in industrial of industrially developing countries? In: Broberg O, Fallentin N, Hasle P, Jensen PL, et al. (eds.) Copenhagen, Denmark.

34. Laitinen H, Rasa PL, Lankinen T (2000) EIMERI: A workplace safety and health observation method. Finnish Institute of Occupational Health Occupational Safety Inspectorate Helsinki.

35. Ghaye T, Lillyman S (2012) Empowerment through reflection: a guide for practitioners and healthcare teams, Reflective practices series ( $2^{\text {nd }}$ edn.) Quay Books, MA Healthcare Limited.

36. Haims MC, Carayon P (1998) Theory and practice for the implementation of "inhouse", continuous improvement participatory ergonomic programs. Applied Ergonomics 29: 461-472.

37. Smith KU, Smith MF (1966) Cybernetic principles of learning and educational design. New York: Holt, Rinehart and Winston

38. Vygotsky LS (1978) Mind and society: The development of higher menta processes. Cambridge, MA: Harvard University Press.

39. Brown JR (2005) Participatory Ergonomics, in Handbook of Human Factors and Ergonomics Methods. In: Stanton N, Hedge A, Brookhuis K, Salas E, Hal Hendrick CRC (eds.) Press LLC. Boca Raton London New York, Washington, DC.

40. Brown JR (2002) Macroergonomic methods: participation, in Macroergonomics: Methods, and Applications. In: Hendrick HW and Kleiner BM (eds.) Lawrence Erlbaum Associates, Mahwah, NJ, pp: 25-44.

41. Lawler Edward E (2006) Built to change: how to achieve sustained organizational effectiveness. Publisher San Francisco, Calif: Jossey-Bass, Chichester: John Wiley.

42. Smith TJ, Smith KU (1988) The cybernetic basis of human behavior and performance. A Newsletter of Ideas in Behavioral Cybernetics, p: 15.

43. Wood DJ, Bruner JS, Ross G (1976) The role of tutoring in problem solving Journal of Child Psychiatry and Psychology 17: 89-100.
Citation: Dastranj F, Helali F (2016) Implementing “Job Enrichment" with using Ergonomic Checkpoints in an 'Appreciative Way' at a Manufacturing Company in an Industrially Developing Country and its Meta-reflection. J Ergonomics 6: 172. doi:10.4172/2165-7556.1000172

\section{OMICS International: Publication Benefits \& Features} Unique features:

Increased global visibility of articles through worldwide distribution and indexing

Showcasing recent research output in a timely and updated manner

Special issues on the current trends of scientific research

Special features:

$700+$ Open Access Journals

$50,000+$ editorial team

Rapid review process

Quality and quick editorial, review and publication processing

Indexing at major indexing services

Sharing Option: Social Networking Enabled

Authors, Reviewers and Editors rewarded with online Scientific Credits

Better discount for your subsequent articles

Submit your manuscript at: http://www.omicsonline.org/submission 